\title{
Eastern extension of the geographic range of Mico emiliae
}

\author{
Roberto Portella de ANDRADE, Italo MOURTHE, Victor SACCARDI, Emil José HERNÁNDEZ-RUZ \\ Universidade Federal do Pará, Programa de Pós-graduação em Biodiversidade e Conservação, Rua Coronel José Porfírio, 2515, Esplanada do Xingu, 68.372-040, \\ Altamira, PA, Brazil \\ * Corresponding author: emilhjh@yahoo.com
}

\section{ABSTRACT}

The distribution of the callitrichids inhabiting the Tapajós-Xingu interfluvium is still poorly understood, probably because of the limited number of studies in this remote region. Mico emiliae is a callitrichid endemic to Brazil, occurring between the Jamanxim and Teles Pires rivers, and Serra do Cachimbo in the west and Iriri River in the east, in the states of Pará and Mato Grosso. However, its current distribution is still uncertain. After ca. 430-km surveys in Serra do Pardo National Park, we successfully confirmed the occurrence of this species for the first time approximately $180 \mathrm{~km}$ east of its previously known eastern limit in Pará. Our records expand the distribution of M. emiliae to the left bank of the Xingu River, increasing the known extent of its occurrence by $83 \%$.

KEYWORDS: eastern Amazonia; Snethlage's marmoset; species distribution

\section{Extensão oriental da distribuição geográfica de Mico emiliae}

\section{RESUMO}

A distribuição dos calitriquídeos que habitam o interflúvio Tapajós-Xingu ainda é pouco conhecida, provavelmente devido ao limitado número de estudos que ocorreram nesta regiáo remota. Mico emiliae é um calitriquídeo endêmico do Brasil que ocorre na região limitada pelos rios Jamanxim e Teles Pires e pela Serra do Cachimbo ao oeste e Rio Iriri ao leste, nos estados do Pará e Mato Grosso. Entretanto, sua distribuição ainda é incerta. Após ca. $430 \mathrm{~km}$ de levantamentos no Parque Nacional da Serra do Pardo, nós confirmamos a ocorrência desta espécie pela primeira vez aproximadamente $180 \mathrm{~km}$ ao leste de seu limite oriental reconhecido no Pará. Esses novos registros expandem a distribuição de $M$. emiliae até a margem esquerda do rio Xingu, aumentando sua extensão de ocorrência em $83 \%$.

PALAVRAS-CHAVE: Amazônia oriental; Sagui-de-Snethlage; distribuição de espécies

The Tapajós-Xingu interfluvium is a remote region in southeastern Brazilian Amazonia. The area contains a number of indigenous territories and protected nature reserves (Martins et al. 1988; Pimenta and Silva Jr. 2005). Thirteen primate taxa occur in this interfluvium (Pimenta and Silva Jr. 2005). However, due to the difficulties resulting from the great number of rapids in the rivers and the numerous indigenous territories located there, this region (especially the central part of the interfluvium) has received only a limited number of studies. Consequently, the distribution of several primates inhabiting this region is still poorly understood (Martins et al. 1988; Pimenta and Silva Jr. 2005), particularly in the case of the small callithrichids. Accurate knowledge of the distributions of these primates is urgently needed because this region is the subject of extensive government-backed development plans (e.g., hydroelectric power dams, mining, road paving), as well as other anthropogenic activities, including hunting, logging, and ranching activities (Pimenta and Silva Jr. 2005).
Snethlage's marmoset (Mico emiliae Thomas, 1920) is a small callithrichid endemic to the remote forests of the Teles Pires/Iriri interfluvium (Ávila-Pires 1986; Fialho 2010; Garbino 2011). This species is considered Data Deficient by IUCN and ICMBio (Rylands and Silva Jr. 2008; Fialho and Canale 2015) because the precise limits of its distribution, as well as its population status, are uncertain. It occurs as far north as the lower Iriri River, reaching the right banks of the Jamanxim and Teles Pires rivers, and Serra do Cachimbo to the west. To the east it reaches the left bank of the Iriri River. The southernmost record comes from the region of Cláudia, located south of the left margin of the Peixoto de Azevedo River, a tributary of the Teles Pires, in the state of Mato Grosso (Figure 1; Ávila-Pires 1986; Martins et al. 1988; Pimenta and Silva Jr. 2005; Rylands and Silva Jr. 2008; Fialho 2010; Garbino 2011; Fialho and Canale 2015). Although the eastern limit of the species is currently defined by the left bank of the Iriri River, the main tributary of the Xingu River, it is likely to extend to the left 


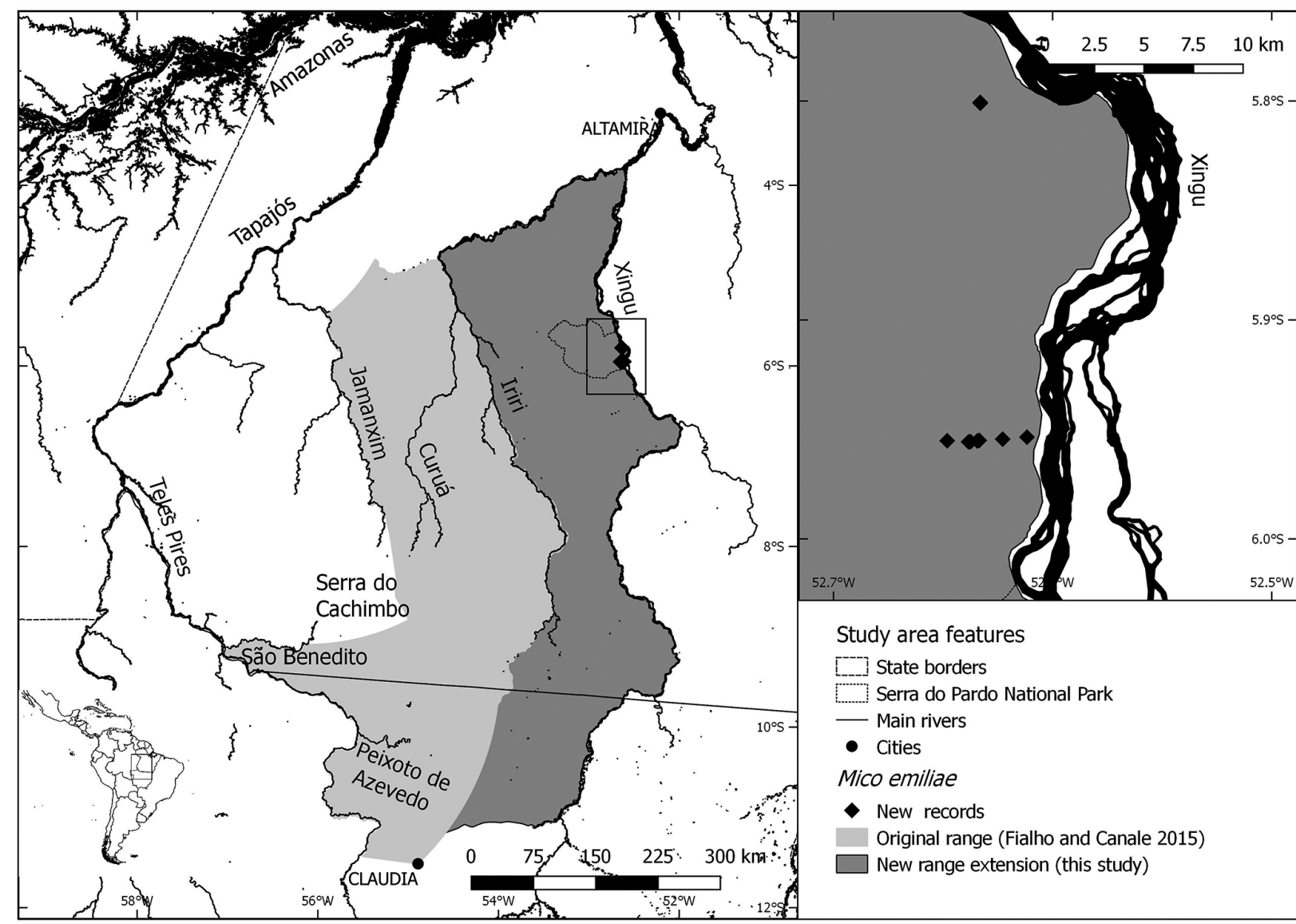

Figure 1. Geographic range of Mico emiliae in the southern Brazilian Amazon.

bank of the Xingu River (Martins et al. 1988; Emmons and Feer 1997; Ferreira 2010). However, this suggestion remained unconfirmed until the present study. Here we report the first record of $M$. emiliae east of the Iriri River, thus extending its distribution to the left bank of the Xingu River.

The study was carried out in the Serra do Pardo National Park, on the left bank of the Xingu River (Figure 1), during March and April 2016, and April, September and October 2017. The Serra do Pardo National Park comprises an area of $446,552 \mathrm{ha}$, and the predominant local vegetation is classified as ombrophilous open forest, within the Amazonian domain (ICMBio 2015). We conducted replicate line-transect surveys following a standardized protocol (Peres 1999), in two preestablished $5-\mathrm{km}$ transects, separated by some $16 \mathrm{~km}$ from each other. Transect 1 was parallel to the river, and Transect 2 was perpendicular to the river. We conducted surveys on foot, and covered a total of $c a .430 \mathrm{~km}$. When possible, we made videos and took pictures of encountered individuals. We did not capture or manipulate any animal. We subsequently determined species identity using illustrations and diagnostic characters described in the literature, including the presence of a typical blackish crown, white brow, unpigmented face, pigmented naked ears, grayish-brown back, and black tail (Figure 2; Ávila-Pires 1986; Garbino 2011).

Through direct observation we obtained 11 records of $M$. emiliae in Serra do Pardo National Park (Table 1), including single individuals ( $\mathrm{N}=2$ sightings), and groups containing from two to three individuals each ( $\mathrm{N}=9$ sightings). Visual contact duration ranged from $15 \mathrm{~s}$ to $2 \mathrm{~min}$. During this time, the observed individuals showed some agonistic behaviors such as restlessness, alertness, and alarm calling (https://www. youtube.com/watch?v=9SyzQ1PBtK8). They were apparently disturbed by our presence, clearly indicating that they were not habituated to human observers. We made all observations between $0900 \mathrm{~h}$ and $1300 \mathrm{~h}$, except one made at $1600 \mathrm{~h}$. All observations were made in regenerating areas covered with lianas, surrounded by high canopy forests, although $M$. emiliae was not observed in this latter forest type.

We have successfully confirmed the occurrence of $M$. emiliae approximately $180 \mathrm{~km}$ east of its previously known eastern limit (Figure 1). Our records extend the eastern range of this species to the left bank of the Xingu River, adding an additional area of approximately $112,906 \mathrm{~km}^{2}$ to its original range $\left(136,716 \mathrm{~km}^{2}\right)$, totaling $249,622 \mathrm{~km}^{2}$. This new area expands the original range of this species by 


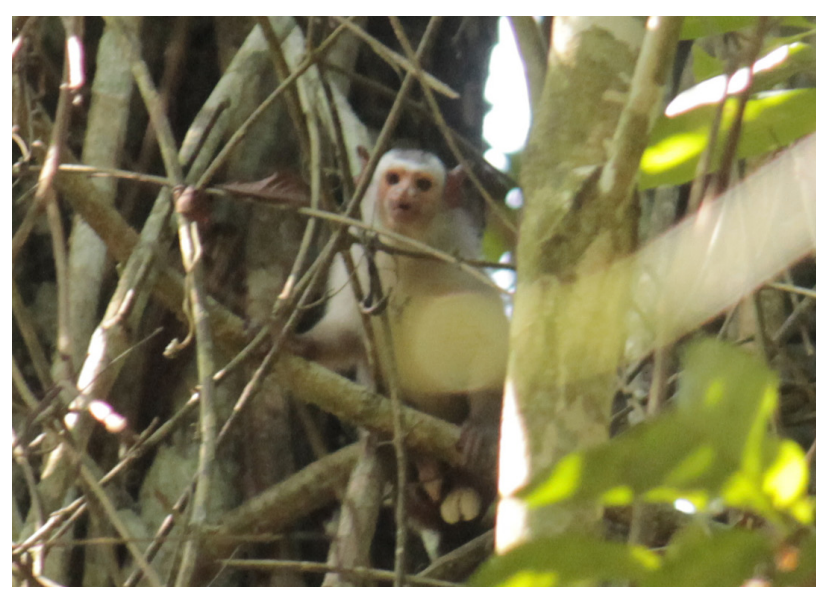

Figure 2. Adult male Mico emiliae recorded in Serra do Pardo National Park, Pará, Brazil. Photo credit: Patrícia D. A. Costa. This figure is in color in the electronic version.

83\%. Mico emiliae has not been previously reported from the Iriri-Xingu interfluvium, although previous researchers have suggested or reported its occurrence in the headwaters of the Xingu River in Mato Grosso (Emmons and Feer 1997; van Roosmalen et al. 2000; Garbino 2011). As small primates have limited dispersion across large rivers (Ayres and CluttonBrock 1992; Peres et al. 1996), we believe that M. emiliae gained access to the Iriri-Xingu interfluvium from the south, probably crossing the narrower headwaters of the Iriri River. Although the eastern and western limits of this species appear primarily constrained by large rivers (e.g. Teles Pires, Xingu), the southern limit is probably the result of the floristic and physiognomic characteristics of the transition between the evergreen seasonal forests of the headwaters of the Xingu River and the Cerrado vegetation of the Midwest Brazilian plateau (Ivanauskas et al. 2008). In turn, we have no clear information on the northern limit of the distribution of the species.

It is unlikely that M. emiliae is distributed homogeneously throughout the Iriri-Xingu interfluvium. For instance, although the Terra do Meio Ecological Station lies in the north of the new extended range reported herein, one of us spent several hours surveying two transects in the northern part of this reserve (total effort: $120 \mathrm{~km}$ ) but recorded no encounters with M. emiliae (Andrade 2016). However, vocalizations of a species of Mico were recorded in this reserve, suggesting the occurrence of this species (Ferreira 2010). It is likely that M. emiliae is at least rare in this whole region. Further surveys may well result in new locality records, which will help us to understand the role of geographic and ecological barriers such as rivers, elevated areas, and forest types in the distribution of M. emiliae.

\section{ACKNOWLEDGMENTS}

We are grateful to the staff of the Programa Nacional de Monitoramento da Biodiversidade (Monitora/ICMBio/ MMA) for providing the logistics and permits to conduct
Table 1. Sightings of Mico emiliae in Serra do Pardo National Park, Pará, Brazil. Geographic coordinates are in datum WGS 84. N = number of individuals sighted.

\begin{tabular}{lccc}
\hline Date & Transect & $\mathrm{N}$ & \multicolumn{1}{c}{ Geographic coordinates } \\
\hline Mar-28-2016 & 1 & 2 & $05^{\circ} 48^{\prime} 03.8^{\prime \prime} \mathrm{S}, 52^{\circ} 37^{\prime} 58.7^{\prime \prime} \mathrm{W}$ \\
\hline Apr-1-2016 & 1 & 3 & $05^{\circ} 48^{\prime} 03.8^{\prime \prime} \mathrm{S}, 52^{\circ} 37^{\prime} 58.7^{\prime \prime} \mathrm{W}$ \\
\hline Apr-18-2017 & 1 & 1 & $05^{\circ} 48^{\prime} 02.3^{\prime \prime} \mathrm{S}, 52^{\circ} 37^{\prime} 58.8^{\prime} \mathrm{W}$ \\
\hline Mar-30-2016 & 2 & 2 & $05^{\circ} 57^{\prime} 20.6^{\prime \prime} \mathrm{S}, 52^{\circ} 38^{\prime} 17.9^{\prime \prime} \mathrm{W}$ \\
\hline Mar-31-2016 & 2 & 3 & $05^{\circ} 57^{\prime} 16.1^{\prime \prime} \mathrm{S}, 52^{\circ} 37^{\prime} 21.9^{\prime \prime} \mathrm{W}$ \\
\hline Mar-31-2016 & 2 & 2 & $05^{\circ} 57^{\prime} 19.1^{\prime \prime} \mathrm{S}, 52^{\circ} 38^{\prime} 03.7^{\prime \prime} \mathrm{W}$ \\
\hline Sep-4-2016 & 2 & 1 & $05^{\circ} 57^{\prime} 18.7^{\prime \prime} \mathrm{S}, 52^{\circ} 38^{\prime} 53.1^{\prime \prime} \mathrm{W}$ \\
\hline Sep-4-2016 & 2 & 2 & $\mathrm{Not}_{\mathrm{available}}$ \\
\hline Oct-14-2017 & 2 & $2+$ & $05^{\circ} 57^{\prime} 18.1^{\prime \prime} \mathrm{S}, 52^{\circ} 38^{\prime} 00.5^{\prime \prime} \mathrm{W}$ \\
\hline Oct-16-2017 & 2 & 2 & $05^{\circ} 57^{\prime} 12.8^{\prime \prime} \mathrm{S}, 52^{\circ} 36^{\prime} 41.9^{\prime \prime} \mathrm{W}$ \\
\hline Oct-16-2017 & 2 & $1+$ & $05^{\circ} 57^{\prime} 20.3^{\prime \prime} \mathrm{S}, 52^{\circ} 38^{\prime} 14.7^{\prime \prime} \mathrm{W}$ \\
\hline
\end{tabular}

our surveys. We thank Valdenir Bezerra de Morais, Domingos Pereira da Silva, Joel Fidelis Nascimento, Lucivaldo Vieira da Silva, Francisco França Carajá, and Roberlan França de Araújo for their help during the fieldwork. Amely Martins provided the shapefiles of the previous distribution of $M$. emiliae available at the Centro Nacional de Pesquisa e Conservação de Primatas Brasileiros. Alex S. Souza and Leandro M. Sousa helped us in elaborating our map. Patrícia D. A. Costa provided the photograph showed in Figure 2. We thank Victor H. Gonzalez and three anonymous reviewers for their helpful suggestions and comments.

\section{REFERENCES}

Andrade, R.P. 2016. Relaçâo entre acessibilidade e abundância de mamíferos de médio e grande porte na Terra do Meio, AltamiraPA, Brasil. Master's dissertation, Universidade Federal do Pará, Altamira, Pará. 38p.

Ávila-Pires, F.D. 1986. On the validity of and geographical distribution of Callithrix argentata emiliae Thomas, 1920 (Primates, Callithricidae). In: Mello, M.T. (Ed.). A Primatologia no Brasil. v.2. Sociedade Brasileira de Primatologia, Brasília, Distrito Federal, p.319-322.

Ayres, J.M.; Clutton-Brock, T.H. 1992. River boundaries and species range size in Amazonian primates. American Naturalist, 140: 531-537.

Emmons, L.H.; Feer, F. 1997. Neotropical Rainforest Mammals - A Field Guide. Chicago University Press, Chicago, 307p.

Ferreira, J.G. 2010. Avaliação para o diagnóstico primatológico da estaçāo Ecológica da Terra do Meio e do Parque Nacional da Serra do Pardo, Estado do Pará. MMA/ICMBio, Centro de Proteção de Primatas Brasileiros - CPB. Unpublished technical report. 25p.

Fialho, M.S. 2010. Contribuição à distribuição do gênero Mico, (Callitrichidae, Primates) no Médio Teles Pires, Jacareacanga, Pará. Neotropical Primates, 17: 31-32.

Fialho, M.S.; Canale, G.R. 2015. Avaliação do Risco de Extinção de Mico emiliae (Thomas, 1920) no Brasil (http://www.icmbio. gov.br/portal/biodiversidade/fauna-brasileira/estado-de- 
conservacao/7215-mamiferos-mico-emiliae-sagui-de-snethlage. html). Accessed on 14/11/2017.

Garbino, G.S.T. 2011. The southernmost record of Mico emiliae (Thomas, 1920) for the state of Mato Grosso, northern Brazil. Neotropical Primates, 18: 53-55.

ICMBio. 2015. Plano de Manejo Parque Nacional da Serra do Pardo. MMA, Brasília, Distrito Federal, 226p.

Ivanauskas, N.M.; Monteiro, R.; Rodrigues, R.R. 2008. Classificação fitogeográfica das florestas do Alto Rio Xingu. Acta Amazonica, 38: 387-402.

Martins, E.S.; Ayres, J.M.; Valle, M.B.R. 1988. On the status of Ateles belzebuth marginatus with notes on other primates of the Iriri river basin. Primate Conservation, 9: 87-91.

Peres, C.A. 1999. General guidelines for standardizing line-transect surveys of tropical forest primates. Neotropical Primates, 7: 11-16.

Peres, C.A.; Patton, J.L.; Da Silva, M.N. 1996. Riverine barriers and gene flow in Amazonian saddle-back tamarins. Folia Primatologica, 67: 113-124.
Pimenta, F.E.; Silva Jr., J.S. 2005. An Update on the Distribution of Primates of the Tapajós-Xingu Interfluvium, Central Amazonia. Neotropical Primates, 13: 23-28.

Rylands, A.B.; Silva Jr., J.S. 2008. Mico emiliae. The IUCN Red List of Threatened Species (http://dx.doi.org/10.2305/ IUCN.UK.2008.RLTS.T42691A10732949.en). Accessed on $14 / 11 / 2017$.

van Roosmalen, M.G.M.; van Roosmalen, T.; Mittermeier, R.A.; Rylands, A.B. 2000. Two new species of marmoset, genus Callithrix Erxleben, 1777 (Callitrichidae, Primates), from the Tapajós/Madeira interfluvium, South Central Amazonia, Brazil. Neotropical Primates, 8: 2-18.

RECEIVED: $16 / 12 / 2017$

ACCEPTED: 28/03/2018

ASSOCIATE EDITOR: Fernanda Michalski 